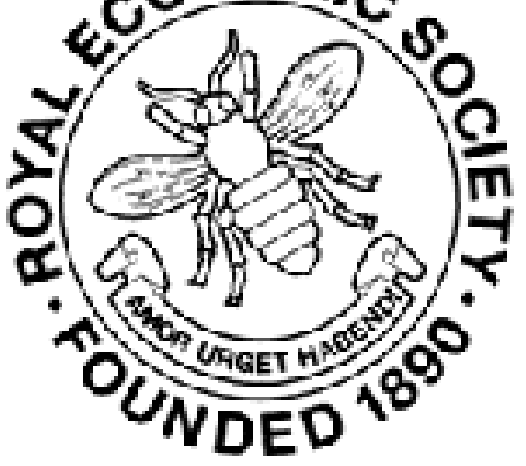

Notes on the Social and Economic Transition in Japan

Author(s): Trevor Johnes

Source: The Economic Journal, Vol. 31, No. 121 (Mar., 1921), pp. 50-60

Published by: Wiley on behalf of the Royal Economic Society

Stable URL: http://www.jstor.org/stable/2223288

Accessed: 26-06-2016 20:26 UTC

Your use of the JSTOR archive indicates your acceptance of the Terms \& Conditions of Use, available at

http://about.jstor.org/terms

JSTOR is a not-for-profit service that helps scholars, researchers, and students discover, use, and build upon a wide range of content in a trusted digital archive. We use information technology and tools to increase productivity and facilitate new forms of scholarship. For more information about JSTOR, please contact support@jstor.org.

Royal Economic Society, Wiley are collaborating with JSTOR to digitize, preserve and extend access to The Economic Journal 


\section{NOTES ON THE SOCIAL AND ECONOMIC TRANSITION IN JAPAN}

THE economic development of modern Japan has followed closely the lines of evolution of European nations in their transition from the feudal to the industrial state. Yet we see day by day, as it were, the drama of nineteenth-century England being enacted over again-the passage from status to contract, the decline of domestic industry and the rise of the factory system, the growth of large towns and the migration from country to town, the decline of guild control of crafts, the rise of trade unionism and the refusal of government authority to admit the principle of collective bargaining, reform bill agitations, rice riots, and, with the application of science to industry and life, the growth of a shallow and callous rationalism. With these developments before one's eyes it is difficult to believe that Japan is only half a century removed from mediævalism. It is a curious phenomenon, and one which Japanese frequently explain by saying: "Japan has accomplished in fifty years what it took England three centuries to do.". Though these facts make it appear that Japan has leapt from the feudal ages right into the nineteenth century, a consideration of the details of this transition shows how gradual it is and how the history of the past fifty years has followed closely the lines of economic and political evolution of Western nations in their transition from mediævalism to modern times.

In our own history the Elizabethan age marks the parting of the ways and the foundation of a new economy over the ruins of the old feudal order, and the facts and movements of this age form a convenient yet true angle from which to view the evolution of modern Japan. Indeed, the conditions, the economic policy and the national organisation of the Elizabethan age are so strikingly similar to those of the Meiji era (1867-1912) of Japan that a comparison throws in relief much that is vague in both ages, and at least is an aid to the understanding of the measure and significance of Japan's development.

The opening of both ages found each nation surrounded and 
even menaced by nations whose feudal order had passed away generations earlier; in the case of Japan by the industrial states of Europe and America, states that had already developed a money economy, commerce, and industries; and, further, had amassed capital enabling them to maintain well-equipped armies of mercenaries quite outmatching the old levies of feudal retainers. The existence of these armies and navies and their evident efficiency had an important bearing on subsequent economic policy and thought, for they were to both the Elizabethans and modern Japan a first demonstration of the existence and importance of a third factor in the production of wealth, namely, capital. In his introduction to the commercial history of the Elizabethan age Dr. Cunningham dwells on this point so well illustrated in Japan's modern history: "In Western Europe, as early as the fifteenth century, the command of wealth in a readily exchangeable form was of supreme importance with a view to international conflicts. Landed proprietors with their retainers could not hold their own against professional soldiers; the prince who commanded large feudal levies was likely to be worsted by an enemy whose purse enabled him to put well-trained mercenaries in the field. A large territory manned with dependents was no longer such a source of strength." 1 To insist on the importance of money and the power of capital as a third factor in the production of wealth may appear superfluous to Western minds to-day; but it is an idea which slowly and with utmost difficulty took root in Europe, and has hardly yet dawned in the minds of Eastern nations. In Europe, the traditional feudal prejudices against trade and usury and the struggles of a sound banking system to free itself from the stigma of usury are sufficient evidence of the slowness of society to realise the importance of money, and the difficulty of the emergence of capital as a factor in the production of wealth.

1 This point cannot be emphasised too much in the case of Japan, for an understanding of it would do much to eradicate the illusion that a sudden admiration for Western civilisation induced the nation to a self-conscious attempt to adopt it. When Western warships appeared off and bombarded the coasts of Japan before the wondering eyes of levies of feudal retainers the feudal military pride of the clans received such a rude shock that they quickly saw that the only way to beat these "red-haired barbarians" was with their own weapons. Only later did the idea dawn that these powerful war machines were based on money expenditure, and to get money commerce and industry are necessary, and these latter cannot be developed without skill and technical knowledge. And thus arose the necessity for planting Western technical education on Japanese soil, and with this educational system came some knowledge of European culture and ideals. Naturally they tackled these problems with that fixed feudal prejudice against peoples whose life, expecially whose military organisation, is based on money and not service. 
Such prejudices and difficulties Japan had to overcome fifty years ago, and it is to this awakening to the idea of money and the necessity of a money economy which Dr. Cunningham notes as the basis of Elizabethan policy that we must turn for explanation of Japan's circumstances.

The economic task, therefore, that presented itself to the Meiji (1867-1912) generation of Japan was the building up of a money economy, and the amassing of capital, primarily, to place her army and navy on a money basis rivalling in efficiency those mercenary forces that had menaced her feudal existence. Thus there was developed in Japan an economic policy, not only administered, but initiated, by a strong national Government whose careful attention to detail and watchfulness over the country's resources has its counterpart in England in that studied, vigilant economic policy associated with the name of Burleigh. The aims and motives of Burleigh provide an elucidation of Japan's economic policy.

Of the elements of Elizabethan government, it is the predominant position of the Council, not merely as legislator and administrator, but as the initiator of commercial policy and enterprise that is most instructive as elucidating the nature of Japan's government to-day. Though Japan has a Constitution ostensibly based on modern Western models, the Diet has little power and little important influence on the nation's affairs. ${ }^{1}$ The predominant position of the Council, as of the "Government" of Japan, rested not so much on bureaucratic power, but rather on the fact that it was the symbol of national as opposed to feudal government, and the reverences for its many ordinances were those of a people who for the first time in their history were

1 The extent of constitutionalism in Japan may be understood from the following facts :-

The electorate numbers 3,000,000 (population 60,000,000).

The Ministers of Army and Navy retain office through a change of "Government."

The "Government" may make disbursements out of revenue without the consent of the Diet, under the head of sekinin shishitsu, "responsibility disbursements."

At the recent general election (May) the Tokyo journal Hochi drew attention to the custom prevailing in some electoral districts of the police canvassing on behalf of the "Government" candidates. The journal was not so severe on the police for using their good offices in favour of the "Government" party, but complained bitterly that in some districts canvassers for the Opposition had been imprisoned.

A constitutional question arose at the same election when two prefectural governors were elected to the Diet. The "Government" decided they should be allowed to take their seats.

The Tokyo Asahi in a recent leader criticised "the War Office's Foreign Policy." 
beginning to feel a nation, merging their clan spirit and their spirit of feudal allegiance into one great idea of nationalism. This type of government is frequently described as bureaucracy, but the term hardly explains the peculiar and less patent nature of the Elizabethan Council, or first National Government of Japan. The sanction of authority rests on something quite different--on the confidence felt in the protection of a strong Central Government by peoples having their first experience of nationhood.

The new National Government of modern Japan threw the full weight of its authority into the development of a carefully designed commercial policy. In his development of new industries, mineral resources, ordnance, in the importation of foreign capital and skill, his currency reforms and the close investigation of every new patent and project, Burleigh held a watching brief for the development of every possible national resource, which, for its close association of the Government with business and commercial policy, has its counterpart in modern Japan. The significance of this association cannot be emphasised too much. The Queen herself wrote pamphlets on currency depreciation in her own hand, and in both ages this peculiar association of the Government with business policy was due to the sudden comprehension of a new factor and power in the destiny of the nation-money.

With the advent of money and Western capitalism in Japan the country was given its first opportunity to place its feudal levies on a money basis with modern armaments, and in doing so it enjoyed an advantage which the Elizabethans did not, in the existence of a well-organised international armament traffic. British and European armament syndicates found here a new and promising market for their wares, and these, together with the aid of foreign military and naval instructors, played an important part in the rapid conversion of Japan's feudal levies into a modern army based on money supplies. ${ }^{1}$ The supply of ordnance was one of the first problems Burleigh had to solve, and his difficulties in this connection were increased by the loss of Calais, which had always given England access to Continental mineral resources. As an island Power in juxtaposition to a continent of vast mineral resources Japan's position is

1 "The most fashionable firms, Krupp, Creusot, Vickers, Armstrong, etc., sell very largely to foreign Governments. The directors form syndicates and enter into agreements for exploiting virgin markets."-(F. W. Hirst.) Their achievements in exploiting Eastern markets is very similar to that accomplished by gunpowder for the Revival of Learning in Europe. 
analogous, and from the importance of Calais to the Elizabethans may be realised the importance to Japan of points on the China coast, such as Port Arthur and Tsingtao, and what lines her motives and policy toward this continent must take.

In developing the industries of the country Burleigh imported freely foreign skill, capital, and patents, and, like modern Japan, was not slow to see how these things could be utilised to the best advantage of the country. Japan's method in this respect is to watch new industrial developments in the West, and the inventions or processes being in a fairly advanced stage, to buy up patents, mechanics, and experts, and reproduce the model on Japanese soil. Thus six months after its production in the West the model may be reproduced in Japan. The patents and skill having been purchased, it is not difficult to find the capital, since the foreign owners of the patent may usually be counted on for considerable investment, thus securing the initial success of the reproduction on Japanese soil. A great problem that Burleigh had to face was the concentration of the foreign trade of the country into the hands of his own nationals, and ridding the country of the Hanse merchants. In the early years of Meiji (18671912) the whole of Japan's foreign trade was in the hands of foreign resident merchants. On the other hand, their position was never so strong as that of the Hanse. They have never enjoyed discriminating favours from the reigning monarch of Japan in the way of free imports; on the contrary, every possible discrimination has been exercised against them. The Hanse must have owed a good deal of their prestige and strength to the fact that in their commercial treaties and official dealings they negotiated direct with governmental authorities and not through consular and diplomatic bodies. The following figures of goods carried to and from Japan in foreign and Japanese bottoms gives some idea of the extent to which the foreign trade of the country is passing into native hands :-

$\begin{array}{rrrrr} & & \text { Total imports } & \text { Carried in } & \text { Carried in } \\ \text { and exports. } & \text { Japanese ships. } & \text { foreign ships. } \\ 1905 & \ldots & \text { Y801,614,964 } & \text { Y63,025,075 } & \text { Y738,589,889 } \\ 1918 & \ldots & \text { Y3,542,006,015 } & \text { Y3,110,820,197 } & \text { Y431,185,818 }\end{array}$

One Yen $=2 s .0 .582 d$.

On the abolition of feudalism, and in her first attempts to establish a monetary and banking system, Japan's early financial difficulties were identical with those of the Elizabethans. In feudal times the nucleus of a banking system had always been present, not in goldsmiths as in Europe, but in a class of pawnbrokers and exchange dealers whose functions were dealing in 
exchange of the currencies of the various daimyates, and making loans to samurai against their future rice allowances. Though each daimyate had its own subsidiary currency, there circulated throughout the whole country a gold coin, koban, exchanging with silver in the ratio $7: 1$. The appearance of the white man on Japanese soil synchronised with the disappearance of this low-priced gold, and the Japanese do not easily forget this early drain of their gold reserve. It handicapped them severely in their first commercial relations with monetised nations, and it is partly due to this and to prevent further gold drain from excess imports that an import tariff on some 650 articles has been maintained. This first experience with nations on a money economy gave the country its first valuable education in money, and how the Elizabethans profited by a similar experience is shown in the work of Sir Thomas Gresham, whom it induced to formulate wisdom on the matter that is still embodied in our text-books on currency. The late war helped Japan to retrieve her position, as the following figures show :-

$\begin{array}{ccc} & \begin{array}{c}\text { Excess exports of gold and } \\ \text { silver bullion. } \\ \text { Yen. }\end{array} & \begin{array}{c}\text { Excess imports of } \\ \text { gold and silver } \\ \text { bullion. } \\ \text { Yen. }\end{array} \\ 1911 \ldots \ldots \ldots \ldots \ldots \ldots . & 18,230,018 & - \\ 1912 \ldots \ldots \ldots \ldots \ldots \ldots . & 16,780,802 & - \\ 1913 \ldots \ldots \ldots \ldots \ldots \ldots . & 26,071,995 & - \\ 1914 \ldots \ldots \ldots \ldots \ldots \ldots . & 20,542,854 & - \\ 1915 \ldots \ldots \ldots \ldots \ldots \ldots . & 20,269,506 & 72,950,483 \\ 1916 \ldots \ldots \ldots \ldots \ldots \ldots . . & - & 238,488,627 \\ 1917 \ldots \ldots \ldots \ldots \ldots \ldots . & - & \mathbf{4 , 0 7 8 , 4 4 8} \\ 1918 \ldots \ldots \ldots \ldots \ldots \ldots . & - & \mathbf{7 8 , 8 9 7 , 0 9 0}\end{array}$

Once the early currency difficulties were surmounted, the banking system of the country was entirely reorganised on Western models. The American national banks were taken as the first models and the regulations of these banks entirely adopted. In 1883, however, an Act took away the issuing privilege of the national banks, confining it solely to the newlycreated Bank of Japan.

In grafting certain features of nineteenth-century Europe on to her post-feudal organisation, Japan enjoyed a certain "unearned increment" by coming late in time, and adopting the perfected mechanism, patents and processes she found ready at hand in the industrialised West. Her population, 30 million in 1867, is to-day 60 million, a contrast with the three or four million of Tudor England, and a fact which shows the necessity of the speedy 
adoption of capitalism and Western industrial methods. How rapid her expansion has been may be seen from the following figures :-

\begin{tabular}{|c|c|c|c|c|}
\hline \multicolumn{5}{|c|}{ National Revenue (IN Yen). } \\
\hline 1875 & 1905 & 1913 & 1919 & \\
\hline 69 & 535 & 721 & 1064 & \\
\hline & Formign & Trade (Imports & and Exports). & $\begin{array}{l}000,000 \text { 's } \\
\text { omitted }\end{array}$ \\
\hline 1885 & 1905 & 1913 & 1918 & \\
\hline
\end{tabular}

In the cotton industry, one of Japan's most formidable enterprises, the following figures illustrate the comparative growth :-

Aferage Annual Consumption of Raw Cotton (1914-16).

Japan.

$830,000,000 \mathrm{lbs}$.
England.

$1,854,000,000 \mathrm{lbs}$.

These amounts of raw cotton were consumed by :-

Japan.

$2,747,778$ spindles.
England. $150,000,000$ spindles.

These are the average number of spindles worked in each country for the years 1914-16 inclusive. Japanese spindles worked an average of twenty hours a day.

In all these developments the country has enjoyed a great advantage by developing late in time. For, in laying down plant and machinery for new industries and adopting new processes, it has been able to utilise the last-improved ideas and machinery of the West, particularly of the United States, and thus it had no traditions nor heavy investments of fixed capital to handicap it, as, for example, is the case with some industries in Europe and America where expensive plant and machinery was laid down years ago, and the industries are bound to remain in their conservative position because not sufficient is written off annually for improvements and the exploitation of new ideas. The country has not had to go through that long apprenticeship of patient trial, research and experiment by which the industry of the West was built up; it has had merely to pluck the ripened fruit.

The figures quoted above take no account of the numerous minor industries in the country engaged in the production of such exotic products as pianolas, pianos, violins, etc., nor of the innumerable minor enterprises in which directly or indirectly the Government interests itself with meticulous solicitude, such as fox-farming, horse-breeding, sheep-rearing, artificial breeding of salmon, model factories for the teaching of scientific management, 
to the rearing of frogs for food. No idea appears too small for development, and for such care in utilising and developing every iota of technical knowledge there is hardly a precedent in our own Government's history, save perhaps in the national policy of the country under Burleigh. Added to this, the hedging around and protection of industry by means of tariffs, subsidies, navigation Acts, and various anti-foreign discriminations, there has developed to-day in Japan that system of national economy against which Adam Smith in his day directed his attackmercantilism.

Much criticism has been directed against Japan's mercantilism, yet it is no more than the line of policy each nation of Europe has taken when the various municipal and feudal units were first merging and beginning to develop national consciousness, and the nation's historical evolution is a modern testimony to the truth of Schmoller's characterisation of the mercantile system : "The essence of the system lies, not in some doctrine of money or the balance of trade, not in tariff barriers, protective duties, or navigation laws, but in something far greater, viz., in the total transformation of society and its organisation, as well as of the State and its institutions, in the replacing of a local territorial economic policy by that of the national State." This transformation dates, in the case of Japan, from 1867, when Meiji Tenno was restored to the throne as Emperor, and four years later the feudal clans were dissolved, and land registers handed in to the new National Government.

Thus mercantilism did its work in welding a new national unity and developing the natural resources of the country after the various daimyos had surrendered their fiefs. It was, as Schmoller describes it, "in its kernel, state-making." Now that the state is made it would be difficult to deny that there have grown up some of those abuses of mercantilism which Adam Smith attacked in his day and which provide a modern illustration of the immortal wisdom of his teaching. An import tariff on some 650 articles yielded, in 1918, $23,500,000$, compared with a yield in England from tobacco alone of $£ 33,000,000$ (1917-18). The constant menace of gold drain from excess imports is the reason put forth for this tariff wall. But one might well ask if there is really an excess of imports and whether it is not just the system of subsidy and subvention that is keeping low the value of exports while their volume is increasing, and whether the average excess of import values throughout the year is not approximately the amount paid away in subsidising exports. 
This might well be the case with the Japanese, who try their hand at the production of every conceivable article of Western consumption, producing a wide variety of articles for export which they can only hope to sell in competition with foreign wares by the methods of subsidy and undercutting. Rather than increase the volume of their exports or their variety, could they make a given volume and range of exports yield a higher price, it might go far to driving away the bogey of gold drain. Such prices could only be obtained by the production of sounder and more efficient goods that could take their stand by foreign goods in open competition, but so long as industries are under the umbrage of subsidies there is no inducement for manufacturers to take this line of policy. These endowments offer too quick and certain returns. Japanese retailed silk goods, for example, are cheaper in London than in Tokyo. It might be expected that Japan's "invisible" exports in the way of shipping earnings might contribute toward the reduction of her excess imports, but here, again, amounts that might aid toward this reduction are largely cancelled by amounts that have been previously paid away in rebates, secret or otherwise, or subsidies. ${ }^{1}$

An analogy of modern Japan with Elizabethan England can do no more than indicate the lines of transition the country's economic life took on the downfall of feudalism, and takes no note of those deeper traits that differentiate an Eastern from a Western nation. But that there should be close analogy is not remarkable if one remembers that, when this hermit nation first opened its doors to foreign intercourse, there were found in existence on its soil all those feudal institutions thought to be peculiar to European feudalism. ${ }^{2}$ In the existence of the family system in Japan and in Shinto, the form of national faith, we see two institutions which make a differentiating mark on the social and political institutions of the country. Shinto, postulating as it does the divinity of the Emperor, developed national patriotism to a point of religious fervour, and is something quite different from our Tudor nationalism.

1 The first Subsidy Act, 1896, provided a subsidy of 25 sen (6d.) per ton gross for every 1,000 miles of service by steamers in foreign trade, provided they had a minimum tonnage of 1,000 gross and a speed of 10 knots. In 1910 the tonnage and speed qualifications were raised to 3,000 tons and $12 \mathrm{knots}$, and the subsidy to 50 sen (1s.).

2 "Notes on Land Tenure and Local Institutions in Old Japan," by D. B. Simmons. Transactions of the Asiatic Society of Japan, Tokyo. Sir William Ashley writes of these notes, "One gets up from the reading of these notes with a quite uncanny feeling. . . . We were not prepared to find that in most essential points mediæval society in Japan was the exact counterpart of that of Europe It is as startling as if we had come on our doubles."-(Surveys.) 
Thus it is not difficult to visualise the drama that is slowly working itself out, a drama in which the clash of motives is provided. by the sudden impact of mediæval custom, mind and state with nineteenth-century industrialism and social philosophy. One watches, for example, the old patriarchal relations between employer and employed survive stubbornly under the capitalised factory system of to-day. So much so that some social thinkers in Japan see in the perpetuation of this "beautiful sentiment" between capital and labour-a sentiment they cannot find in the West-Japan's own peculiar solution to the labour question. ${ }^{1}$ But slowly it is realised that sentiment, however beautiful, is frequently capricious, and that contract being dependable has much to be said for it, at least as a means of regulating economic affairs. One watches, too, what short work the ideas of contract and money make of ancient custom and usage, bringing about a degeneration of loyalty in service and change of occupations, frequently without that efficiency of labour which they have developed in the West. At no time was this more evident than in the years 1914-19, when money poured into the country. It produced unprecedented labour unrest, to some extent encouraged by the achievements of similar unrest in the West. Yet with the difference that in Japan it is not the deliberate unrest of a people accustomed to contract and collective bargaining. To realise its significance one must think of it as the unrest of a people for whom only a generation ago occupations were fixed and hereditary, mobility from place to place difficult, a people who are feeling the first glow of freedom which money payments and the voluntary contracting of their labour can give. The chief danger of such movements in Japan is that they take their

1 Baron Goto, for example, when interrogated by an American as to how this beautiful patriarchal relation between employer and employed came to exist in Japan, replied, "The phenomenon you have noticed is due to the peculiar nature of the Japanese people. In the West the strongest factor in government is reason, logic, and ideas. But here the strongest thing is the heart, if I may call it that-that is to say, sentiment."

Baron Shibusawa, the greatest capitalist of Japan, in a book, "A Hundred Talks," writes : "The relation existing in the past between capitalists and labourers was a relation of feeling and affection. To provide a law and establish this relation on the basis of rights and duties would have the effect of creating distance between them. . . . The hope of social harmony, of a good relation between capitalists and labourers, is to be grounded on the realisation of 'good customs and beautiful sentiments.' . . . If labourers and capitalists alike followed the royal path 'and looked upon it as a rule of human conduct industrial differences and law suits would be avoided. This bond is superior to a hundred statutes and a thousand laws. The true bond is that of sympathy, and the notion of rights and duties can have no other effect than to separate capitalists and labourers." 
inspiration from similar movements in the West, while labour in Japan is far behind Western labour in efficiency. It was precisely to meet such a contingency that the Elizabethan Statute of Artificers and Wage Assessments was intended.

Trevor JoHNES

Government Commerctal College,

Otaru, Japan. 